\title{
EVALUASI KUALITAS PUPUK ORGANIK YANG BEREDAR DI PULAU JAWA BERDASARKAN PERMENTAN NO. 70/SR.140/10 TAHUN 2011
}

\section{Quality Evaluation Organic Fertilizers Marketed in Java Island Based on the Ministrial Agriculture Regulation No.70/Permentan/SR.140/10/2011}

\author{
Triyani Dewi1)*, Iswandi Anas²), Suwarno²), dan Dedi Nursyamsi3) \\ 1) Balai Penelitian Lingkungan Pertanian Jl. Raya Jakenan Km. 5 Kotak Pos 5 Pati 59182 - Jawa Tengah. \\ 2) Departemen Ilmu Tanah dan Sumberdaya Lahan, Fakultas Pertanian IPB, J1. Meranti Kampus IPB Darmaga \\ Bogor 16680 \\ 3) Balai Penelitian Pertanian Lahan Rawa. J1. Kebun Karet, Lok Tabat Kotak Pos 31 Banjarbaru 70712, Kalimantan \\ Selatan
}

\begin{abstract}
In the recent years, there are many commercial organic fertilizers sold in the free market. However, many of these organic fertilizers have not only low quality but some of them are also contain undesirable such as heavy metals. In order to control the quality of commercial organic fertilizers in the market, the Ministry of Agriculture Republic of Indonesia had issued a Ministerial Agriculture Regulation (No.28/Permentan/SR.130/5/2009). This Ministerrial Agriculture Regulation had been renewed with the Ministrial Agriculture Regulation No.70/Permentan/SR.140/10/2011. To evaluate the effectiveness of these regulation to control the quality of organic fertilizer in the market, a study was carried out. As much as 60 organic fertilizer samples in total had been collected from Wast Java (20 samples), Central Java (20 samples) and East Java (20 samples). The samples were collected from the farmers, kiost or fertilizer detailers as well as taken directly from organic fertilizer producers. The samples were analyzed according to the procedures described in the attachment of the Minister Decree. Not all parameters in the Minister of Agriculture Decree No. 702012 were analyzed. The parameters analyzed in this study were water content, $\mathrm{pH}$, Organic-C, Total- $\mathrm{N}, \mathrm{C} / \mathrm{N}$ ratio, $\mathrm{P}_{2} \mathrm{O}_{5}, \mathrm{~K}_{2} \mathrm{O}$, total $\mathrm{Fe}$, available-Fe, heavy metal $\mathrm{Pb}$ and $\mathrm{Cd}$. The analysis were carried out at Integrated Laboratory of Agricultural Environment Research Institute (Laboratorium Terpadu Balai Penelitian Lingkungan Pertanian (Balingtan) at Jakenan, Central Java. The results of this study showed that no single commercial organic fertilizer samples met the criteria in the Minister Decree No No.70/Permentan/SR.140/10/2011. The parameters that mostly did not meet the criteria were water content, $\mathrm{C}$-content, $\mathrm{C} / \mathrm{N}$ ratio, $\mathrm{N}, \mathrm{P}_{2} \mathrm{O}_{5}, \mathrm{~K}_{2} \mathrm{O}$, Total Fe, heavy metal Cd.
\end{abstract}

Keywords: Organic fertilizer quality, Ministrial Agriculture Regulation (Permentan No. 70 2011)

\begin{abstract}
ABSTRAK
Banyak pupuk organik yang beredar di pasaran terutama di Pulau Jawa dengan mutu yang jelas. Berbagai kalangan, baik dari pihak konsumen/pengguna maupun pihak produsen/pembuat. Guna menjamin mutu produk dari suatu produsen pupuk organik yang akan dipasarkan, mendorong pemerintah untuk membuat peraturan yang berkaitan dengan semua aspek tentang pupuk organik. Pemerintah telah menetapkan suatu Peraturan Menteri Pertanian No.28/Permentan/SR.130/5/2009 yang kemudian diperbaharui dengan Peraturan Menteri Pertanian No.70/Permentan/SR.140/10/2011. Meskipun secara legal standar mutu pupuk organik telah dibuat, akan tetapi pada kenyataannya sangat sulit menentukan standar mutu pupuk organik dan di lapangan masih banyak ditemukan kualitas pupuk organik yang masih belum sesuai dengan persyaratan yang telah ditetapkan. Untuk meneliti kualitas pupuk organik yang beredar produksi dan dijual dipasar di Pulau Jawa, serangkaian studi telah dilakukan survei melalui pengambilan contoh pupuk organik di Jawa Barat, Jawa Tengah, dan Jawa Timur baik di tingkat petani, kios/agen, maupun produsen. Contoh-contoh pupuk organik tersebut dianalisis kadar air, $\mathrm{pH}$, serta kandungan haranya yang meliputi kadar C-organik, N-total, rasio $\mathrm{C} / \mathrm{N}, \mathrm{P}_{2} \mathrm{O}_{5}, \mathrm{~K}_{2} \mathrm{O}$, Fe-total, Fe-tersedia, kadar logam berat $\mathrm{Pb}$ dan $\mathrm{Cd}$ di Laboratorium Terpadu Balai Penelitian Lingkungan Pertanian. Dari hasil survei, ternyata tidak ada satupun dari 60 contoh pupuk organik yang diuji yang memenuhi semua persyaratan pupuk organik menurut Permentan No. 70 Tahun 2011.
\end{abstract}

Kata kunci : Kualitas Pupuk Organik, Permentan No. 70 Tahun 2011 


\section{PENDAHULUAN}

Menjamurnya merk-merk pupuk organik yang beredar di pasaran tanpa kejelasan mutu dari setiap merk dan formula yang dicantumkan dalam suatu produk pupuk organik, telah meresahkan berbagai kalangan, baik dari pihak konsumen/pengguna maupun pihak produsen/ pembuat. Guna menjamin mutu produk dari suatu industri yang akan dipasarkan kepada tingkat konsumen, mendorong pemerintah untuk membuat pengaturan yang berkaitan dengan semua aspek yang berkaitan dengan pupuk organik. Untuk mengatur kualitas pupuk organik di pasaran, Pemerintah melalui Kementrian Pertanian telah menerbitkan Permentan No.28/Permentan/SR.130/5/2009. Permentan No. 28/2009 ini telah diperbaharui dengan Peraturan Menteri No.70/Permentan/SR.140/10/2011 tentang Pupuk Organik, Pupuk Hayati, dan Pembenah Tanah. Dasar dari Peraturan tersebut adalah: (1) Aspek filosofi, mengandung arti bahwa pupuk organik dan pembenah tanah sangat berperan dalam mendukung keberhasilan pengembangan budidaya tanaman, (2) Aspek yuridis, berguna untuk melindungi konsumen dan produsen, pupuk organik dan pembenah tanah yang akan dipasarkan di wilayah Republik Indonesia, dan (3) Aspek teknis, persyaratan teknis minimal yang perlu dimiliki oleh suatu pupuk organik dan pembenah tanah.

Permentan No.70/Permentan/SR.140/10/2011, dikemukakan bahwa pupuk organik adalah pupuk yang sebagian besar atau seluruhnya terdiri atas bahan organik yang berasal dari tanaman dan atau hewan yang telah melalui proses rekayasa, dapat berbentuk padat atau cair yang digunakan mensuplai bahan organik untuk memperbaiki sifat fisik, kimia, dan biologi tanah. Definisi tersebut menunjukkan bahwa pupuk organik lebih ditujukan kepada kandungan C-organik atau bahan organik daripada kadar haranya; nilai C-organik itulah yang menjadi pembeda dengan pupuk anorganik. Bila C-organik rendah dan tidak masuk dalam ketentuan pupuk organik maka diklasifikasikan sebagai pembenah tanah organik.

Studi ini bertujuan untuk mengevaluasi kualitas pupuk organik yang beredar di Jawa Barat, Jawa Tengah dan Jawa Timur dengan menggunakan sebagian kriteria yang terdapat di dalam Permentan No. 70/Permentan/ SR.140/10/2011.

\section{BAHAN DAN METODE}

Kegiatan ini diawali dengan survei instansional untuk mencari informasi jenis pupuk organik yang sudah beredar baik yang sudah terdaftar atau yang belum terdaftar di Pusat Perizinan dan Investasi (PPI), Kementrian Pertanian maupun instansi terkait untuk menentukan daerah lokasi pengambilan contoh pupuk organik.

Survei lapangan dilakukan untuk mengetahui kualitas pupuk organik yang beredar di Jawa, diutamakan di kabupaten-kabupaten yang merupakan sentra produksi padi atau sayuran, kemudian dipilih kecamatan-kecamatan yang merupakan wilayah identifikasi berdasarkan informasi dari Dinas Pertanian atau BPP serta instansi terkait. Survei ini dilaksanakan baik di tingkat produsen/pabrik, kios/agen/pengecer, maupun tingkat petani.

Pengambilan contoh pupuk organik dilakukan dari tempat penyimpanan pupuk (gudang), kios-kios, petani atau dari pabrik pupuk. Pupuk yang diambil berbentuk granul padat. Jumlah contoh pupuk organik yang diambil untuk dianalisis disesuaikan berdasarkan jumlah dan macam pupuk yang beredar di lapangan. Untuk pupuk dengan kemasan besar $(50 \mathrm{~kg})$ diambil sebanyak 1 $\mathrm{kg}$, bila terdapat dalam kemasan kecil minimal ukuran $1 \mathrm{~kg}$ diambil seluruhnya (Suriadikarta et al., 2004).

Informasi yang dikumpulkan adalah: (1) nama dagang pupuk dan produsen; (2) tanggal pengambilan contoh; (3) jumlah kantong/karung yang diambil contohnya; (4) bobot contoh pupuk organik yang diambil per kantong atau karung; (5) kandungan hara yang terdapat dalam kemasan pupuk organik, dan (6) nama pabrik/agen/toko/petani beserta alamat. Contoh pupuk organik yang diperoleh dari lapangan dianalisis $\mathrm{pH}$, kadar air, C-organik, N-total, $\mathrm{P}_{2} \mathrm{O}_{5}$ dan $\mathrm{K}_{2} \mathrm{O}$, Fe-total, Fetersedia, kadar logam berat $\mathrm{Pb}$ dan $\mathrm{Cd}$ (Tabel 1). Analisis dilakukan di Laboratorium Terpadu, Balai Penelitian Lingkungan Pertanian, Jakenan, Jawa Tengah.

Tabel 1. Parameter pupuk organik yang dianalisis dan metode analisis yang digunakan (Sulaeman et al., 2005)

\begin{tabular}{|c|c|c|}
\hline Parameter/Kriteria & Satuan & Metode Analisis \\
\hline Kadar Air & $\%$ & Gravimetri \\
\hline $\mathrm{pH} \mathrm{H} \mathrm{H}_{2} \mathrm{O}$ & - & $\mathrm{pH}$ meter \\
\hline $\begin{array}{l}\text { C-Organik } \\
\text { C/N }\end{array}$ & $\%$ & Walkley \& Black \\
\hline \multicolumn{3}{|l|}{ Hara : } \\
\hline $\mathrm{N}$ & $\%$ & Kjeldahl \\
\hline $\mathrm{P}_{2} \mathrm{O}_{5}$ & $\%$ & $\mathrm{HNO}_{3}: \mathrm{HClO}_{4}$ \\
\hline $\mathrm{K}_{2} \mathrm{O}$ & $\%$ & $\mathrm{HNO}_{3}: \mathrm{HClO}_{4}$ \\
\hline Fe-total & ppm & $\mathrm{HNO}_{3}: \mathrm{HClO}_{4}$ \\
\hline Fe-tersedia & ppm & ekstrak DTPA \\
\hline \multicolumn{3}{|l|}{ Logam berat: } \\
\hline $\mathrm{Pb}$ & ppm & $\mathrm{HNO}_{3}: \mathrm{HClO}_{4}$ \\
\hline $\mathrm{Cd}$ & ppm & $\mathrm{HNO}_{3}: \mathrm{HClO}_{4}$ \\
\hline
\end{tabular}

\section{HASIL DAN PEMBAHASAN}

Lokasi pengambilan contoh pupuk organik disajikan pada Tabel 2 yaitu di Jawa Barat (Kabupaten Karawang, Sukabumi, Banjar, Ciamis, Bogor, dan Tangerang), Jawa Tengah (Tegal, Demak, Sukoharjo, Karanganyar, Boyolali, Sragen, Pati, dan Salatiga), dan Jawa Timur (Mojokerto, Gresik, Tuban, dan Surabaya). Dari hasil survei tersebut diambil 60 contoh pupuk organik granul, baik yang berasal dari kios/distributor, produsen/pabrik maupun langsung dari petani. Sebagian besar contoh pupuk organik granul (41 contoh) yang diambil berasal dari pabrik/ produsen karena di tingkat toko/agen/distributor tidak banyak ditemukan pupuk organik granul. 
Tabel 2. Lokasi pengambilan contoh pupuk organik di Jawa Barat, Jawa Tengah dan Jawa Timur dan jumlah contoh yang diambil

\begin{tabular}{llc}
\hline Propinsi & Kota/Kabupaten & Jumlah Sampel yang diambil \\
\hline Jawa Barat & Karawang & 2 \\
& Tangerang & 3 \\
& Sukabumi & 5 \\
& Banjar & 2 \\
& Ciamis & 1 \\
& Bogor & 2 \\
Jawa Tengah & Tegal & 2 \\
& Demak & 7 \\
& Sukoharjo & 2 \\
& Karanganyar & 5 \\
& Boyolali & 1 \\
& Sragen & 1 \\
& Pati & 3 \\
& Salatiga & 2 \\
Jawa Timur & Mojokerto & \\
& Tuban & 14 \\
& Gresik & 2 \\
TOTAL & Surabaya & 2 \\
\hline
\end{tabular}

Hal ini mungkin disebabkan karena adanya Program Bantuan Langsung Pupuk (BLP) dari pemerintah baik pupuk anorganik maupun organik yang diberikan kepada petani/kelompok tani secara cuma-cuma.

Pupuk organik yang digunakan dalam pengadaan BLP ini adalah pupuk yang telah terdaftar dan memenuhi standar mutu berdasarkan ketentuan Perundang-Undangan dalam hal ini Permentan No. 28 Tahun 2009. Pupuk BLP khususnya pupuk organik granul diproduksi dan atau diadakan oleh PT Pertani (Merek Bintang Kuda Laut), PT Sang Hyang Seri (Merek Elang Biru), dan PT Berdikari (merek Berdikari Tani Lestari), (Permentan No 37 Tahun 2010).

Contoh pupuk organik dianalisis di Laboratorium Balai Penelitian Lingkungan Pertanian (Terakreditasi). Hasil analisis sifat kimia pupuk organik disajikan pada Tabel 3.

Tabel 3. Hasil analisis sifat kimia sampel pupuk organik yang disurvei

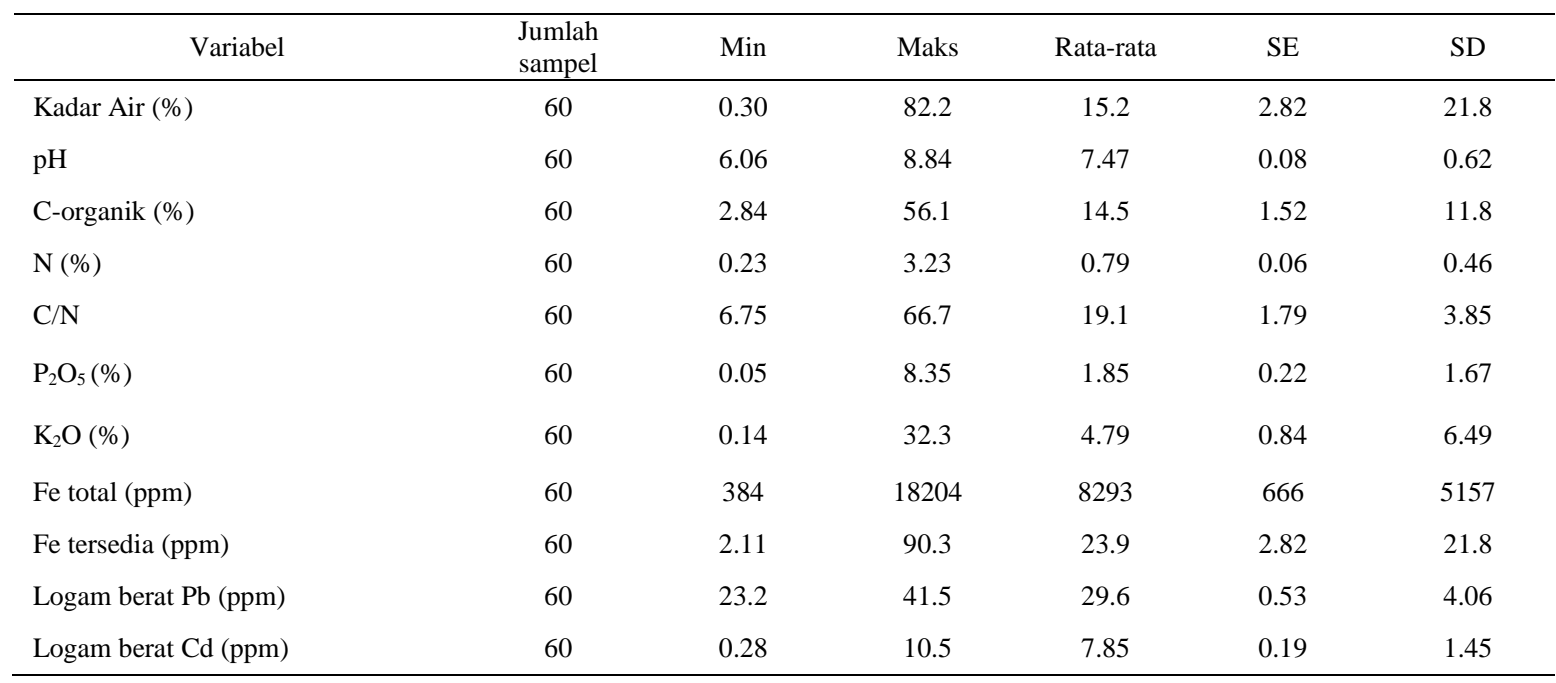

Hasil survei tersebut (Tabel 3) menunjukkan bahwa kadar air yang terkandung dalam pupuk organik bervariasi dari 0.30 sampai $82.2 \%$; pH 6.06 - 8.84, Corganik $2.84-56.1 \%, \mathrm{~N}, \mathrm{P}$, dan $\mathrm{K}$ masing-masing berkisar 0.23-3.23; 0.05-8.35; dan 0.14-32.4\%. Unsur hara mikro Fe baik total maupun tersedia juga logam berat $\mathrm{Pb}$ dan $\mathrm{Cd}$ juga sangat bervariasi nilainya. Bila dihubungkan dengan persyaratan minimal pupuk organik sesuai dengan Peraturan Menteri Pertanian No. 70 Tahun 2011, maka pupuk organik hasil survei semuanya tidak masuk dalam ke dalam kriteria pupuk organik.

Kualitas pupuk organik banyak ditentukan oleh bahan asalnya, sebagai contoh pupuk organik yang berasal dari guano dengan kadar $\mathrm{C}$-organik rendah, $\mathrm{C} / \mathrm{N}$ rasio juga rendah, namun kadar hara $\mathrm{P}$ dan kadar air bisa tinggi (Suriadikarta dan Setyorini, 2006). Bahan dasar pupuk organik yang berasal dari sisa tanaman umumnya sedikit mengandung bahan berbahaya. Namun penggunaan pupuk kandang, limbah industri dan limbah kota sebagai bahan dasar kompos/pupuk organik cukup mengkhawatirkan karena banyak mengandung bahan berbahaya seperti misalnya logam berat.

Gambar 1 menunjukkan kadar Fe-total, Fetersedia, kadar logam berat $\mathrm{Pb}$ dan $\mathrm{Cd}$ dalam contoh pupuk organik yang diambil dari Jawa Barat, Jawa Tengah, dan Jawa Timur. 


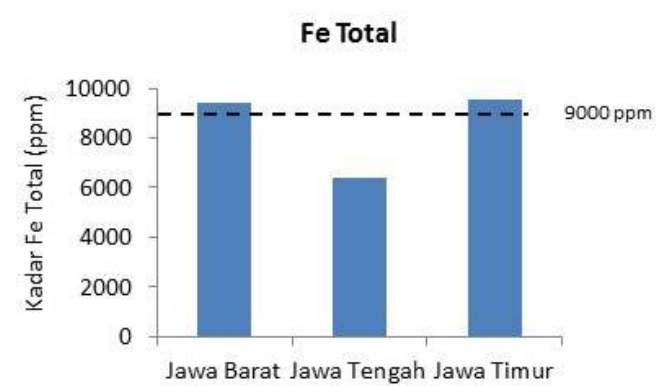

$\mathrm{Pb}$

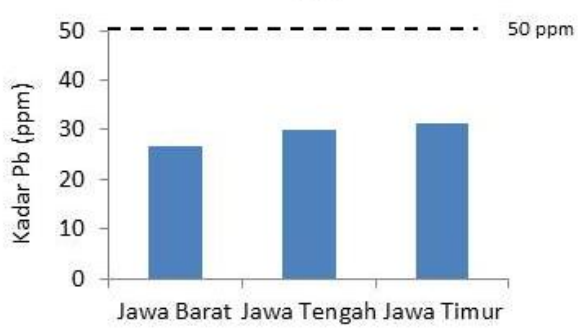

Fe Tersedia

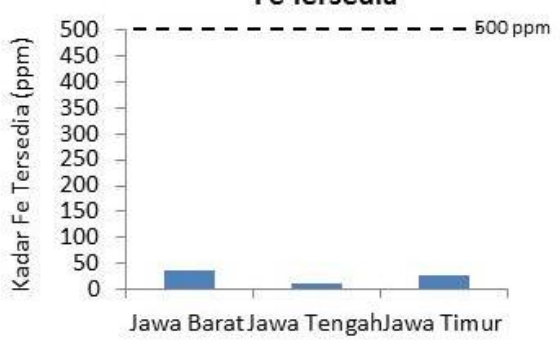

Cd

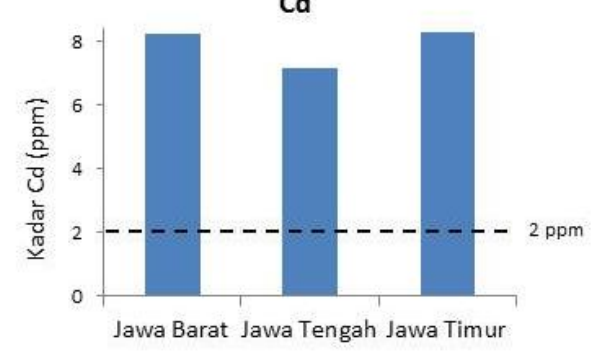

Gambar 1. Kadar Fe Total, Fe ekstrak DTPA, Pb, dan Cd dalam contoh pupuk Organik yang diambil di Jawa Barat, Jawa Tengah dan Jawa Timur. Garis titik-titik menunjukkan batas maksimum untuk setiap kriteria

Kadar Fe-total dalam contoh pupuk organik yang berasal dari Jawa Tengah telah memenuhi persyaratan yang ditetapkan menurut Permentan Bo. 70 Tahun 2011 yaitu sebesar $\leq 9000$ ppm, untuk pupuk organik yang diambil dari wilayah Jawa Barat dan Jawa Timur kadar Fetotal tidak memenuhi syarat yang ditetapkan. Untuk kadar Fe-tersedia dalam pupuk organik ditetapkan maksimal sebesar $\leq 500 \mathrm{ppm}$, dari semua contoh pupuk organik yang diambil baik dari Jawa Barat, Jawa Tengah, dan Jawa Timur semuanya memenuhi persyaratan yang telah ditetapkan.

Penetapan kadar Fe-tersedia baru muncul pada Permentan No. 70 Tahun 2011, sedangkan pada peraturan sebelumnya Permentan No. 28 Tahun 2009 hanya mensyaratkan kadar Fe-total saja. Penetapan kadar besi total maks. 9,000 ppm perlu dicermati kembali, mengingat besi oksidatif tidak aktif bila $\mathrm{pH}>4.0\left(\mathrm{pKa} \mathrm{Fe}^{+3}\right.$ adalah 3 , artinya berbentuk ion bila berada pada $\mathrm{pH}<3$ ). Besi pada umumnya tidak aktif pada tanah yang umumnya dibudidayakan (upland), bila di tanah sawah kemungkinan bentuk besi reduksi $\left(\mathrm{Fe}^{2+}\right)$ lebih disebabkan oleh besi oksida tanah (ekstraksi oksalat) daripada besi reduktif dari total besi yang berasal dari pupuk organik. Tanaman secara umum pada $\mathrm{pH} 4$ lebih keracunan aluminium daripada keracunan besi. Sehingga pada Permentan No. 70 Tahun 2011 mencantumkan persyaratan kadar Fe-tersedia sebagai salah satu parameter yang harus dijadikan bahan pertimbangan dalam menentukan kualitas pupuk organik yang tidak tercantum pada peraturan sebelumnya yaitu Permentan No. 28 Tahun 2009. Selain itu dengan takaran pupuk organik dalam Program BLP kurang dari 1 ton per ha, dengan kadar besi 9000 ppm (0.9\%), hanya ada penambahan besi maksimum $9 \mathrm{~kg}$ per ha (4.5 ppm), sedangkan besi yang terdapat di dalam tanah jauh melebihi nilai tersebut.
Masalah utama dalam produksi pupuk organik/kompos adalah hadirnya logam berat/bahan beracun berbahaya bagi kesehatan manusia dan pertumbuhan tanaman. Bahan dasar pupuk organik yang banyak digunakan dan mengandung bahan berbahaya adalah sampah kota dan limbah cair. Logam berat yang sering terdapat dalam bahan tersebut adalah $\mathrm{Pb}, \mathrm{Cd}$, dan Cr. Unsur-unsur ini akan terserap oleh tanaman, dan tanaman akan termakan oleh manusia yang pada akhirnya akan mengkontaminasi seluruh rantai makanan.

Kadar logam berat $\mathrm{Pb}$ dan $\mathrm{Cd}$ dalam pupuk organik tidak boleh melebihi 50 dan 2 ppm. Dari hasil survei menunjukkan bahwa contoh pupuk organik yang diambil telah memenuhi persyaratan karena kadar $\mathrm{Pb}$ kurang dari 50 ppm, namun jika dilihat dari kadar $\mathrm{Cd}$ semua contoh pupuk organik yang diambil tidak memenuhi persyaratan karena kadar Cd melebihi batas yang ditetapkan yaitu $2 \mathrm{ppm}$. Hal ini disebabkan pada saat pengambilan contoh, produsen pupuk organik pada saat proses produksinya masih mengacu pada peraturan sebelumnya yaitu Permentan No. 28 Tahun 2009 dimana kadar Cd ditetapkan maksimal 10 ppm artinya bila mengacu pada peraturan sebelumnya, semua contoh pupuk organik yang diambil sudah memenuhi persyaratan yang telah ditetapkan oleh pemerintah. Ditambah lagi peraturan yang baru belum tersosialisasikan dengan baik, sehingga informasi mengenai hal ini belum semuanya sampai ke produsen pupuk organik.

Kriteria maksimum logam berat dalam pupuk organik berbeda antara negara. Kriteria disesuaikan dengan kondisi setempat. Di negara bagian Florida, maksimum kadar $\mathrm{Cd}$ dalam kompos adalah $15 \mathrm{ppm}$ dan $\mathrm{Pb}$ 500 ppm, sedangkan di Kanada untuk kadar logam berat yang sama ditetapkn 3 ppm Cd dan 150 ppm Pb sedangkan di Korea Selatan 5 ppm Cd dan 150 ppm Pb (Suriadikarta 
dan Setyorini, 2006). Hasil evaluasi pupuk organik yang beredar di Pulau Jawa berdasarkan Peraturan Menteri Petanian No. 70 tahun 2011 disajikan pada Tabel 4. Tiga kelas evaluasi ini adalah (1) Rendah dari nilai yang diinginkan dalam Permentan No. 70 tahun 2011 tersebut,
(2) Sesuai yang berati memenuhi persyaratan, dan (3) Tinggi yang berarti melebihi nilai yang dikehendaki. Nilai ini disajikan dalam jumlah sample yang masuk ke dalam masing-masing kategori dan diikuti dengan nilai presentase yang disajikan dalam kurung.

Tabel 4. Evaluasi pupuk organik yang beredar di Pulau Jawa berdasarkan Peraturan Menteri Pertanian No. 70 Tahun 2011

\begin{tabular}{clcccc}
\hline No & \multicolumn{1}{c}{ Tolok ukur } & Syarat & Rendah & Sesuai & Tinggi \\
\hline 1. & Kadar air $(\%)$ & $8-20$ & $9(15)$ & $34(57)$ & $17(28)$ \\
2. & $\mathrm{pH}$ & $4-9$ & $0(0)$ & $60(100)$ & $0(0)$ \\
3. & C-organik $(\%)$ & $>15$ & $39(65)$ & $21(35)$ & $0(0)$ \\
4. & $\mathrm{~N}(\%)$ & $\geq 4$ & $60(100)$ & $0(0)$ & $0(0)$ \\
5. & $\mathrm{Rasio} \mathrm{C} / \mathrm{N}$ & $15-25$ & $32(54)$ & $14(23)$ & $14(23)$ \\
6. & $\mathrm{P}_{2} \mathrm{O}_{5}(\%)$ & $\geq 4$ & $57(93)$ & $3(7)$ & $0(0)$ \\
7. & $\mathrm{~K}_{2} \mathrm{O}(\%)$ & $23(72)$ & $17(28)$ & $0(0)$ \\
8. & Fe-tersedia (ppm) & $\leq 500$ & $0(0)$ & $60(100)$ & $0(0)$ \\
9. & Fe-total (ppm) & $\leq 9000$ & $0(0)$ & $30(50)$ & $30(50)$ \\
10. & $\mathrm{~Pb}(\mathrm{ppm})$ & $\leq 50$ & $0(0)$ & $60(100)$ & $0(0)$ \\
11. & $\mathrm{Cd}(\mathrm{ppm})$ & $\leq 2$ & $0(0)$ & $1(2)$ & $59(98)$ \\
& Memenuhi syarat & & & $0(0)$ & \\
\hline
\end{tabular}

Keterangan : Angka dalam kurung adalah persentase

Dari hasil evaluasi pupuk organik yang beredar di Pulau Jawa (Tabel 4), dengan dasar persyaratan yang terdapat dalam Permentan No. 70 Tahun 2011, maka pupuk organik yang disurvai, memiliki C-organik, $\mathrm{N}$, rasio $\mathrm{C} / \mathrm{N}, \mathrm{P}_{2} \mathrm{O}_{5}, \mathrm{~K}_{2} \mathrm{O}$ yang rendah karena berada di bawah nilai yang dipersyaratkan dalam Permentan tersebut. Nilai $\mathrm{pH}$ dan kadar Fe-tersedia seluruhnya memenuhi persyaratan, namun masih banyak kriteria yang melebihi dari kriteria dalam Permentan No 70 Tahun 2011 yaitu masih tingginya kadar air, rasio $\mathrm{C} / \mathrm{N}$ dan kadar Fe-total dari pupuk organik. Pupuk organik yang di survei di Jawa Barat, Jawa Tengah, maupun Jawa Timur secara keseluruhan tidak ada yang memenuhi persyaratan menurut Permentan No. 70 Tahun 2011.

\section{SIMPULAN}

Tidak ada satupun dari 60 contoh pupuk organik yang beredar di Pulau Jawa yang memenuhi semua persyaratan pupuk organik menurut Permentan No. 70 Tahun 2011.

\section{UCAPAN TERIMA KASIH}

Penelitian ini dibiayai oleh Badan Penelitian dan Pengembangan Pertanian melalui program KKP3T tahun 2011, Institut Pertanian Bogor. Kepada sdr Cahyadi, SP dan Wismajaya yang telah turut membantu kelancaran penelitian ini, diucapkan terima kasih.

\section{DAFTAR PUSTAKA}

Anonim. 2005. Pupuk organik tingkatkan produksi pertanian. Warta Penelitian dan Pengembangan Pertanian 27 (6). Balai Penelitian Tanah. Bogor.

Peraturan Menteri Pertanian. 2009. No.28/Permentan/SR.130/5/2009 Tentang Pupuk Organik, Pupuk Hayati, dan Pembenah Tanah.

Peraturan Menteri Pertanian. 2010. No. 37/Permentan/SR.130/5/2010 Tentang Pedoman Umum Bantuan Langsung Pupuk Tahun Anggaran.

Peraturan Menteri Pertanian. 2011. No. 70/Permentan/SR.140/10/2011 Tentang Pupuk Organik, Pupuk Hayati, dan Pembenah Tanah.

Sulaeman, Suparto, dan Eviati. 2005. Petunjuk Teknis Analisis Kimia Tanah, Tanaman, Air, dan Pupuk. Balai Penelitian Tanah. Badan Litbang Pertanian. Departemen Pertanian.

Suriadikarta, D.A., D. Setyorini, dan W. Hartatik. 2004. Petunjuk Teknis Uji Mutu dan Efektivitas Pupuk Alternatif Anorganik. Balai Penelitian Tanah. Puslitbangtanak. Badan Penelitian dan Pengembangan Pertanian. Bogor.

Suriadikarta, D.A. dan D. Setyorini. 2006. Baku Mutu Pupuk Organik. Pupuk Organik dan Pupuk Hayati. Balai Besar Litbang Sumberdaya Lahan Pertanian. Badan Litbang Pertanian. 